\title{
On-line Shopping Trends, Patterns and Preferences of University Undergraduate Students: A Survey Study on Sylhet Region
}

\author{
Md. Mahbubur Rahaman
}

Senior Lecturer, Department of Business Administration, Leading University, Sylhet, BANGLADESH

\begin{abstract}
With the explosion of the e-commerce in the past decade, different buying patterns and preferences have emerged for customer groups and other demographics. These patterns have been measured and collected by numerous independent marketing, business and even academic studies to understand how consumers connect with the new adventure of e-commerce. As the internet and online shopping is growing at a very fast pace worldwide, investigating this trend within Bangladeshi context is crucial considering that it is a relatively new trend in the country, the result is a lack of literature. This paper consists of the groundwork with a brief introduction of recent trends in e-commerce on people of Bangladesh; particularly its impact on university undergraduate students in Sylhet region. This has been followed by their general perceptions and preferences of the online shopping including products and website selection. Each of these e-commerce "characteristic" is compared to information combined from survey questions and open-ended discussions with a small sample group of university students at undergraduate level in Sylhet region. It also investigates into positive as well as negative website characteristics and sum up the favorable elements into a description of an e-commerce website that would suitable to the group being studied. Findings have been presented by means of the formation identified during the data analysis, indicated that an increasing number of the students at undergraduate level are now using the internet for purchase. It also observed that between male and female students, male students are purchasing products online more than female students. Although student's participation is increasing, there are some limitations for what the potential numbers of students are not able to purchase via online.
\end{abstract}

Key Words: On-line shopping, Trends, Preferences, Undergraduate students JEL Classification Code: A22; Z13

\section{INTRODUCTION}

The Internet's impact on people has been profound; particularly with respect to buyers, who are starting to use the Internet as a new medium to trade and purchase goods and services. In the early years of e-commerce, buying online was an intellectual activity strictly dominated by "techies" and semi-technology literate individuals. These individuals were mostly made up of 20 to 35 year old males and were professional people. 
This demographic was more comfortable and in tune with Internet's capabilities. But in recent years, the number of students (male and female) also making the technology to increase online shopping is regular. Students are initiating to the harness of Internet to make their personal and academic lives easier and efficient. The contemporary flow has generated all sorts of new data on student's online trends, patterns and preferences.

\section{LITERATURE REVIEW}

Online retail sales are estimated to grow from $\$ 172$ billion in 2005 to $\$ 329$ billion in 2010 [Johnson 2005]. There are 32 countries worldwide with the Internet penetration rate higher than 50\% (http:/ /www.internetworldstats.com). As of April 2006, 73\% of American adults are Internet users (http:/ / www.pewinternet.org).

The consumer-oriented view focuses on consumers' salient beliefs about online shopping. Such beliefs may influence purchase channel selection. For example, online consumer behavior has been studied from the perspectives of consumer demographics [ Stafford et al. 2004], cognitive / psychological characteristics [Hoffman and Novak 1996; Huang 2003; Lynch and Beck 2001; Novak et al. 2000; Wolfinbarger and Gilly 2001; Xia 2002], perceptions of risks and benefits toward online shopping [Bhatnagar and Ghose 2004a; Bhatnagar and Ghose 2004b; Bhatnagar et al. 2000; Featherman and Pavlou 2003; Garbarino and Strabilevitz 2004; Huang et al. 2004; Jarvenpaa and Todd 1997; Jarvenpaa and Tractinsky 1999; Jarvenpaa et al. 1999; Joines et al. 2003; Kolśaker et al. 2004; Liang and Jin-Shiang 1998; Liao and Cheung 2001; Park et al. 2004; Pavlou 2003; Pires et al. 2004; Solomon 1999], shopping motivation [Childers et al. 2001; Johnson et al. 2004; Novak et al. 2000; Wolfinbarger and Gilly 2001], and shopping orientation [Donthu and Garcia 1999; Korgaonkar and Wolin 1999; Li et al. 1999; Swaminathan et al. 1999].

[Lina Zhou, Liwei Dai \& Dongsong Zhang 2007] summarized individual factors and their impact on consumer online shopping, they identified nine types of consumer factors, including demographics, Internet experience, normative beliefs, shopping orientation, shopping motivation, personal traits, online experience, psychological perception, and online shopping experience. Among these, demographics were the focus of early studies, while psychological perception and online experience (e.g., emotion) have been examined in more recent studies. It is not surprising that some consumer factors were found to have consistent effects across different studies while others were found to have mixed or even contradictory impacts. To enable better understanding of the results, they provided alternative explanations for some of the mixed findings. In addition, they analyzed how the importance of the nine factors evolves over time.

Table: Consumer Factors related to Online Shopping

\begin{tabular}{|c|c|c|c|}
\hline Factor Types & $\begin{array}{c}\text { Individual } \\
\text { Factors }\end{array}$ & Surveyed Studies & Major Findings \\
\hline \multirow[t]{2}{*}{ Demographics } & Gender & $\begin{array}{l}\text { [Alreck and Settle 2002; } \\
\text { Brown et al. 2003; Donthu } \\
\text { and Garcia 1999; Korgaonkar } \\
\text { and Wolin 1999; Levy 1999; } \\
\text { Li et al. 1999; Rodgers and } \\
\text { Harris 2003; Slyke et al. 2002; } \\
\text { Stafford et al. 2004] }\end{array}$ & $\begin{array}{l}\text { Male consumers make more online } \\
\text { purchases and spend more money } \\
\text { online than females; they are equally } \\
\text { or more likely to shop online in the } \\
\text { future, and are equally or more } \\
\text { Ifavorable of online shopping. Women } \\
\text { have a higher-level of web } \\
\text { apprehensiveness and are more } \\
\text { skeptical of e-business than men. }\end{array}$ \\
\hline & Age & $\mid \begin{array}{l}\text { Bellman et al. 1999; } \\
\text { Bhatnagar and Ghose 2004b; }\end{array}$ & $\begin{array}{l}\text { There are mixed findings on the } \\
\text { relationship between age and online }\end{array}$ \\
\hline
\end{tabular}




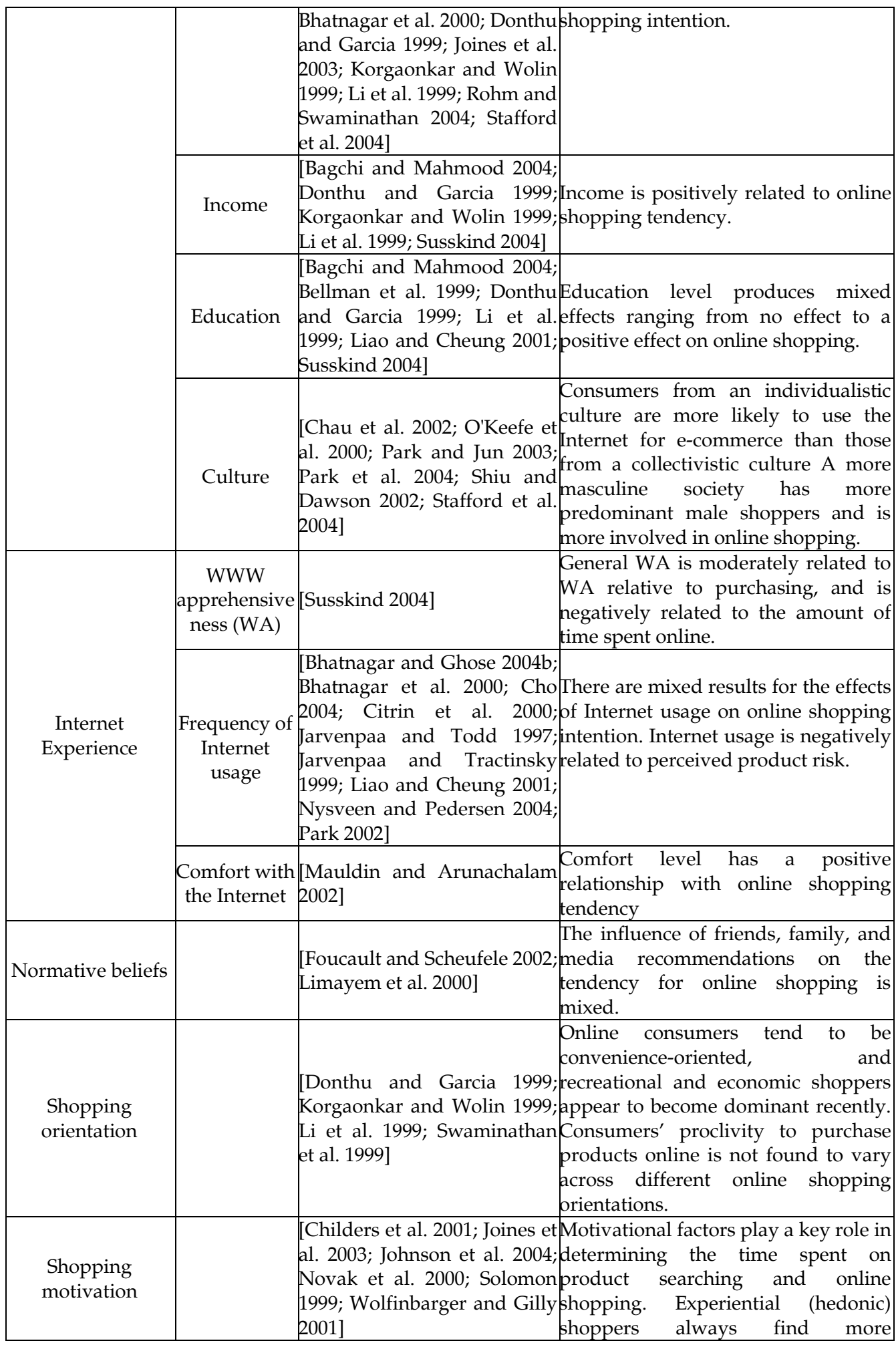




\begin{tabular}{|c|c|c|c|}
\hline & & & $\begin{array}{l}\text { enjoyment } \begin{array}{c}\text { in } \\
\text { environments than in pure text } \\
\text { environment. }\end{array} \\
\end{array}$ \\
\hline Personal traits & $\begin{array}{c}\text { Innovativene } \\
\text { ss }\end{array}$ & $\begin{array}{l}\text { [Citrin et al. 2000; Donthu } \\
\text { and Garcia 1999; Goldsmith } \\
\text { 2001; Goldsmith 2002; } \\
\text { Limayem et al. 2000; Sin and } \\
\text { Tse 2002] }\end{array}$ & $\begin{array}{l}\text { Personal innovativeness has both } \\
\text { direct and indirect effects on online } \\
\text { shopping intention, the indirect } \\
\text { effects being mediated by attitude. }\end{array}$ \\
\hline \multirow[b]{2}{*}{ Personal traits } & Emotion & $\begin{array}{l}{[\text { Huang 2003; Lynch and }} \\
\text { Beck 2001; Wolfinbarger and } \\
\text { Gilly 2001; Xia 2002] }\end{array}$ & $\begin{array}{l}\text { Positive emotions have a positive } \\
\text { influence on online shopping } \\
\text { intention in some countries. }\end{array}$ \\
\hline & Flow & $\begin{array}{l}\text { [Hoffman and Novak 1996; } \\
\text { Mathwick and Rigdon 2004; } \\
\text { Novak et al. 2000] }\end{array}$ & $\begin{array}{l}\text { There are mixed results on the } \\
\text { influences of flow on positive } \\
\text { subjective experience and greater } \\
\text { exploratory behavior. }\end{array}$ \\
\hline \multirow[t]{3}{*}{$\begin{array}{l}\text { Psychological } \\
\text { perception }\end{array}$} & $\begin{array}{c}\text { Risk } \\
\text { perception }\end{array}$ & $\begin{array}{l}\text { [Bhatnagar and Ghose 2004a; } \\
\text { Bhatnagar and Ghose 2004b; } \\
\text { Bhatnagar et al. 2000; } \\
\text { Featherman and Pavlou 2003; } \\
\text { Garbarino and Strabilevitz } \\
\text { 2004; Huang et al. 2004; } \\
\text { Jarvenpaa and Todd 1997; } \\
\text { Jarvenpaa and Tractinsky } \\
\text { 1999; Jarvenpaa et al. 1999; } \\
\text { Joines et al. 2003; Kolśaker et } \\
\text { al. 2004; Liang and Jin-Shiang } \\
\text { 1998; Liao and Cheung 2001; } \\
\text { Park et al. 2004; Pavlou 2003; } \\
\text { Pires et al. 2004] }\end{array}$ & \\
\hline & $\begin{array}{l}\text { Benefit } \\
\text { perception }\end{array}$ & $\begin{array}{l}\text { [Chen et al. 2002; Limayem et } \\
\text { al. 2000; Pavlou 2003] }\end{array}$ & $\begin{array}{l}\text { Perceived usefulness is positively } \\
\text { related to the intention to purchase } \\
\text { online. }\end{array}$ \\
\hline & \begin{tabular}{|c|} 
WWW \\
purchasing \\
apprehensive \\
ness
\end{tabular} & [Susskind 2004] & $\begin{array}{l}\text { WWW purchasing apprehensiveness } \\
\text { is negatively related to the amount of } \\
\text { money spent online }\end{array}$ \\
\hline \multirow{2}{*}{$\begin{array}{c}\text { Online Shopping } \\
\text { experience }\end{array}$} & $\begin{array}{c}\text { Frequency of } \\
\text { online } \\
\text { purchases }\end{array} \mid$ & $\begin{array}{l}{[\text { Brown et al. 2003; Cho 2004; }} \\
\text { Foucault and Scheufele 2002; } \\
\text { Moe and Pader 2004; Park } \\
\text { and Jun 2003; Yang and } \\
\text { Lester 2004] }\end{array}$ & $\begin{array}{l}\text { Frequency of purchases is positively } \\
\text { related to online shopping tendency } \\
\text { and negatively related to the } \\
\text { likelihood to abort an online } \\
\text { transaction. }\end{array}$ \\
\hline & \begin{tabular}{|c|} 
Satisfactory \\
levels about \\
past online \\
transactions
\end{tabular} & $\begin{array}{l}\text { [Cho 2004; Devaraj et al. } \\
\text { 2002; Foucault and Scheufele } \\
\text { 2002; Koivumi 2001; Pires et } \\
\text { al. 2004] }\end{array}$ & $\begin{array}{l}\text { Previous satisfaction has a positive } \\
\text { relationship with online shopping } \\
\text { tendency. }\end{array}$ \\
\hline
\end{tabular}

Source: "Online Shopping Acceptance Model- A Critical Survey of Consumer Factors in Online Shopping," Journal of Electronic Commerce Research, Vol. 8, No.1, pp 1-4.

Traditionally, shopping is an activity more favored by women. It is women who are usually in charge of household shopping and hold more positive attitudes towards the traditional store and catalogue shopping than their male counterparts [Alreck and Settle (2002)]. However, the new shopping channel provided by the Internet seems to result in a different if not opposite, gender a pattern. Although there was no significant difference between online shoppers and non-shoppers in terms of gender [Donthu and Garcia 1999], 
men were found to make more purchases [Li et al. 1999; Stafford et al. 2004] and spend more money online [Susskind 2004] than women. Men's perceptions of online shopping were approximately the same as [Alreck and Settle 2002] or even more favorable than [Slyke et al. 2002] those of female consumers.

Such a change of gender pattern in the online shopping environment has been explained using different models or factors, including shopping orientation [Rodgers and Harris 2003; Swaminathan et al. 1999], information technology acceptance and resistance [Rodgers and Harris 2003; Susskind 2004], product involvement [Slyke et al. 2002], product properties [Citrin et al. 2003], and perceived risks [Garbarino and Strabilevitz 2004]. First, shopping orientation was found to influence consumers' shopping activities, interests, and opinions. Men and women were found to have different shopping orientations-men were more convenience-oriented and less motivated by social interaction while women were just the opposite [Swaminathan et al. 1999]. The function of shopping online as a social activity is weak compared to shopping in traditional stores. This is due to the lack of face-to-face interaction with sales associates online. Women did not find online shopping "as practical and convenient as their male counterparts" ([Rodgers and Harris 2003], page 540).

Second, the products that male and female consumers are interested in buying are different. For example, male consumers are more interested in hardware, software, and electronics, while females are more interested in food, beverages, and clothing. In the early stage of e-commerce, the types of products available online used to be male-oriented [Slyke et al. 2002]. Women did not shop online because they could not find products that interested them.

Third, women demonstrate a stronger need for tactile input in product evaluation than men [Citrin et al. 2003]. The inability to touch or try on products, a shortcoming of online purchasing, might also result in fewer female online shoppers. This characteristic affects online purchase negatively, particularly for those products that require more tactile cues for their evaluation (e.g., shoes).

Consumer needs, interests and attitudes vary with age, and the youngest consumers have the most positive attitude toward innovation [Darian 1987; Modahl 2000; Mulhern 1997; Rogers 2003; Schiffman and Kanuk 2003; Steenkamp, Ter Hofstede and Wedel 1999; Wotruba and Pribova 1995]. Given that the variable age influences attitude towards these new medium, participants in group 2 was over 40 years old, while those in the other groups were aged between 18 and 25. In the context of interactive shopping, cultural characteristics also influence shopping patterns [Park and Jun 2003; Van Birgelen, De Ruyter, De Jong and Wetzels 2002]. Thus, consumers from individualist cultures develop a more innovative profile and are more predisposed to shop via Internet than consumers from cultures which favour collectivism [Jarvenpaa, Tractinsky, Saarinen and Vitale 1999; Steenkamp, Ter Hofstede and Wedel 1999]. For this reason, the participants in the group 1were Spanish university students (students from low-individualist cultures), while those in group 3 were Norwegian and German students, i.e. from highly individualist cultures.

Mishra (2009) studied the use of Internet at the University of Maiduguri, Nigeria. The findings showed that Internet was very significant for $60.8 \%$ of the respondents, with $74.6 \%$ using the Internet for research; 71.5\% mentioned Google as their preferred search engine and concludes that necessary facilities should be put in place for faculty and students to make optimal use of information resources available on the Internet.

Andrew Keen (2009) writes in his book, 'The Cult of Amateur' that Internet is an easy to use platform to distribute ignorance and hatred. But he further argues that rather than being technology's fault, we are collectively to blame for the new media gloom. 
Because of the internet's social and economic value for the human society our reliance on it has recently increased and become a fundamental pillar, and its informational and interactive capability has increased, and accompanies this is that the relations are not fixed and it is difficult predict the effects of long-term use (Majali, 2007).

Research conducted by Deloitte Access Economics (2011) confirm that retailers have become much more active in taking advantage of the internet to place and take orders, but they are not as perceptive as businesses in other industries of the potential benefits from internet transaction activity.

\section{ObJective OF the Study}

The main objective of this study is to review the trends, patterns and preferences of University Undergraduate students about online shopping in Sylhet region. The specific objectives are:

- To discover out behavioral characteristics of online shoppers;

- To find out website selection criteria and items that they are looking for;

\section{Methodology of the Study}

Research methodology mainly focused on quantitative method and survey study considered as a research technique.

Population:

Since the study is about Trends, Patterns and Preferences of University Honors Level Students as online shoppers in Sylhet. The population in this study is all the undergraduate students' of different private and public universities in the Sylhet region.

Sample:

The sample in the study was selected randomly from the population considering that all the respondents of the group have a general or conceptually understanding of the Internet. It is assuming that all of the respondents have prior experience with the Internet. That is, the respondent has experience accessing and navigating the web. Additionally, all of the respondents have knowledge of the ability of shopping online, not necessarily having essentially purchased something online. In this study 100, students selected randomly throughout the Sylhet city among six public and private universities.

Data collection method:

A structured questionnaire was formed before the interview started. All the questions pertained exclusively to the subject of online shopping. Prepared questions in the survey mixed between closed-ended questions expecting concise answers to open-ended questions, which required more elaboration of sample respondent's online experience and perceptions of electronic purchasing. As a contingency to any complications in describing web concepts or confusion in terminology, the prepared questions, reinforced by an open discussion with each sample respondent on topics relating to the purchasing, improved the understanding, depth and clarity of the sample respondent's online experience. Since the surveys were performed face-to-face, the number of questions in the survey was not predetermined. This flexible approach meant that if a respondent volunteered information that were within the scope of the subject matter contained in the question, more questions could be raised to gather more data. The surveys were conducted primarily in respondent's university premises. Respondent's who preferred to have surveys conducted at their residence had the opportunity to demonstrate how they navigate various shopping sites and their thoughts about the site. The available literature have been used through reviewing different articles, books, periodicals, journals, magazines, published reports, and relevant websites. 
Data Analysis technique:

Collected data will be analyzed by using appropriate statistical tools based on descriptive statistics.

Constraints:

I could not use larger sample size due to time and situational constraints. The non-random sampling techniques have also been a constraint in ensuring external validity of the outcomes of the study. However the nature and methods of interviewing have been adapted to limit such. The paper makes only very generalized and unconfirmed conclusions about buying patterns and perceptions of this particular demographic, although the survey uses statistical methods for analyzing the collected data for better understanding.

\section{Projection of Findings AND ANALysis}

Trends of online shopping: The mean value of the internet shopping frequency is 1.42 on a 5 point scale. Among the respondents, $46 \%$ are experienced with online shopping and $51 \%$ of them purchase one to three times in which is not encouraging for the online merchant as well for the economic development of the country. This means the average shopper has made very few number of shopping over the internet. The vital reasons behind this low frequency can be found in further queries made in the questionnaire. Among the respondents, $51 \%$ lacks availability of credit cards / debit cards that are the main reason for the students not to purchase online. Also $60 \%$ are concern about the reliability of online shopping; $58 \%$ are threatened by the possibility of internet crime, 51\% complains they can't feel the physical products and $27 \%$ said that the delivery process are very slow. These are the constraints that cause students not to purchase online on a regular basis. Also, $96 \%$ respondents said that they usually physically go to the shop for shopping. Because, they enjoy physical shopping as it is reliable to them, they really can touch and feel the products. Some of the respondents are saying that shopping is a social experience where they can meet with people who are very dear to them and also a chance to meet with people what can't be happen in online shopping. The respondents reported not shopping, meaning not purchasing anything online on a regular basis, but admitted to browsing products online or "window shopping" online at least on regular or weekly basis.

Reasons of purchasing online: The most cited reason by the respondents for using the Web for personal shopping of is the Internet's convenience and simplifies their lives. The study has found four reasons i.e. time saving, security, convenient and easiness of the system has been the vital reasons to shopping online by the respondents. Among the respondents, $67 \%$ are saying that online shopping is time saving that is most important for people of fast moving world and so are the people of Bangladesh. It also seen that $89 \%$ are showing their consent that the internet shopping system is very simple, $57 \%$ are showing their reliability about the security and $70 \%$ are saying the online shopping system is a convenient way for people that should encourage the people who are related with online shopping system for their survive and also flourish business in local and global market. Because, in an extreme time constrained schedule and transportation hassle, the respondents who shop online found online shopping as a convenient option for time saving. Also, carrying cash is often felt risky. For this reason, internet shopping sites with a reputation of shoppers' security have been the choices of the respondents.

Products and Services buying online: Software \& books, sports items, music, gifts \& toys have been the most chosen products to be purchased over the internet shopping sites among the respondents. Total $90 \%$ of respondents said that they liked to purchase 
software and books on internet, $80 \%$ likes to purchase music, gifts and toys, and $60 \%$ like to purchase sports items. As people don't like to face the hassle and carry anything with them, they prefer to buy all the items online because internet is the most appropriate place to purchase such items where they can get the products instantly after payment. In the case of sports items, internet is proving different types of items that even can't be imagined in physical shopping. On the other hand, mobile, computers, electronics, fashion, jewelry, cosmetics, grocery \& home products, tickets, personal items, furniture other food items have been on the less favored option for the online shoppers. Among the respondents, $54 \%$ are saying that they don't like to purchase mobile, computer and electronics items online as they want to touch and feel the products before making the purchase. $52 \%$ of respondents prefer physical shopping of fashion products, cosmetics and jewelry than online for receiving these items immediately after purchasing and for the matter to show people about their taste and style. $82 \%$ of respondents said they disliked purchasing furniture on the internet because if they purchase furniture on the internet it would be costly for them. $67 \%$ of respondents they are not familiar with online buying of tickets and for the lack of credit / debit cards. $67 \%$ of respondents said they don't prefer buying food items on the internet, though they have a positive sense about it. The main problem is most of the surveyed respondents belongs to the middle class family and online buying food items charge more than if they buy these items from any shop or restaurant and freshness of some food items also not allow them to buy online.

Students' feelings about security of shopping online: About the security of online shopping respondents are feeling secure themselves, although $65 \%$ of the surveyed respondents are confident about the security aspects of the online shopping sites; a low percentage $(<20 \%)$ of them feels confident about making a secure purchase online. The vital reasons may be their feeling of unfamiliarity with the internet shopping protocols and systems. Also, the perceived lack of ability in identifying trusted shopping sites may be another reason for this atypical confidence level.

Students' experience of buying online: Many of the respondents displayed more comfort and satisfaction with well known and established e-tailers like Cell bazaar. On the other hand, the experience of shopping at other lesser known e-tailers was a little more worrying to a few of the sample members. Among the online shoppers found in the survey, nearly $70 \%$ of them are satisfied with their online shopping experience to a varying extent. However, nearly 30\% shoppers are dissatisfied and may spread negative word of mouth about the shopping sites or even online shopping as a whole.

Most appealing sites that students visit: Among the favored sites, $100 \%$ respondents said facebook.com, youtube.com, google.com, cellbazaar.com, yahoomail.com and gmail.com has been the most popular ones as they used these sites for information, communication and study objectives. Alongside, 90\% said ebay.com, $89 \%$ said amazon.com, 70\% said bdjobs.com, $73 \%$ said bikroy.com, $71 \%$ said tickets.com, $60 \%$ said buy.com, and $48 \%$ said cricinfo.com are popular and perceived useful to them. On the other hand, nettop24.com, dior.com, tech24.com, autoblog.com, cookinglight.com, and worldofwathces.com have not been found useful enough and thus are less favored by the respondents.

Website elements students looking for: The mostly searched element on the internet by the respondents has been information and communication. Here, google.com, yahoo.com, gmail.com, facebook.com, twitter.com, linkedin.com, etc. sites are found very convenient by them. For the purpose of entertainment, youtube.com, google.com, cricinfo.com and facebook.com has been most accepted. For leads on new products and places, 
newproduct.com, amazon.com, ebay.com, cellbazar.com, google.com, tripadvisor.com, bdtrip.com, etc. sites are among the favorites. For news and jobs, bdjobs.com, prothomalo.com, prothomalojobs.com, news24.com, dailystar.com, etc. are privileged most by the respondents.

Purchase Trends and Patterns of male and female students: If the internet shopping behavior trends of the male and female respondents are compared the internet usage rate is almost same among the two group but female respondents are keener on checking information over the internet prior to any purchase. On the other hand, in terms of frequency of purchase, number of purchases made and perceived comfort in online shopping, male respondents are at a higher position than that of the female respondents.

\section{ConcLusion}

Based on the information collected from this small sample group, it can be said that people are trying to familiar and habituated with online shopping. But the internet infrastructure and socio-economic condition of Bangladesh does not allow the e-tailers as well as the actual and potential customers to remain and become optimistic about the new business concept of e-commerce. Also, the dependency of students is another constrain. By looking at what students want and their satisfaction levels some established e-tailers such as Cell Bazaar and Bikroy.com have been invested significant resources in this sector. Perhaps it would be useful for Cell Bazaar and Bikroy.com in Bangladeshi perspective to imitate some of the world's established e-tailers such as Amazon, eBay and others to maintain large numbers of students as their customer.

\section{REFERENCES}

Akkas, Ali, Kibria \& Bin, Md. Jubair, 2010, "E-Commerce: Comparison of On-line Shopping Trends, Patterns and Preferences- Based on a Selected Survey of Women," Journal of Business Studies, pp 2-8.

Al Majali, Abd Salam, Ahmad \& Althoneibat, Abd Karim, Yassar Ghassan, 2012 "Trends of Graduate Students in the University of Mu'tah to the Negative Effects of the use of the Internet and how to Reduce them," American Journal of Scientific Research, ISSN 2301-2005 Issue 65 (2012), pp. 5-8.

Bankole, M Olubanke, \& Babalola, O Stephen, "Internet Use Among Undergraduate Students of Olabisi Onabanjo University, Ago Iwoye, Nigeria," Library Philosophy and Practice, Viewed December 20, 2012, http://digitalcommons.unl.edu/cgi/viewcontent.cgi.

Bigne, E. Ruiz, C. and Sanz, S., 2005, "The Impact of Internet User Shopping on Consumer Mobile buying Behaviour," Journal of Electronic Commerce Research, Vol. 6, No.3, p 5.

Chandio, Ahmed J., 2011, "Usage Trend of Internet Time by Undergraduate University Students," Journal of Managerial Sciences, Volume VI Number 2, p 3-5.

Eden, D., Dziuban, C. \& Walker, D J., 2012, "ECAR Study of Undergraduate Students and Information Technology," Educause Center for Applied Research, pp 4-7.

Narges Delafrooz, Laily H. Paim, Sharifah Azizah Haron1, Samsinar M. Sidin and Ali Khatibi, 2009, "Factors affecting students' attitude toward online Shopping," African Journal of Business Management, Vol. 3 (5), pp. 3-8.

Nysveen, H. and Pedersen, P., 2004, "An Exploratory Study of Customers' Perception of Company Web Sites offering Various Interactive Applications: Moderating Effects of Customers' Internet Experience," Decision Support Systems Vol. 37, No. 1: pp137-150.

Zhou, L. Dai, L. and Zhang, D., 2007, “Online Shopping Acceptance Model- A Critical Survey of Consumer Factors in Online Shopping," Journal of Electronic Commerce Research, Vol. 8, No.1, pp 1-4. 
APPENDIX -01:

\section{Frequencies}

\begin{tabular}{|c|c|c|c|c|c|c|c|c|c|c|c|}
\hline & & 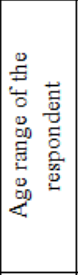 & 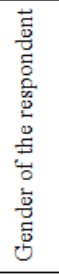 & 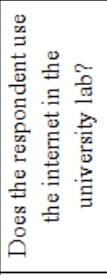 & 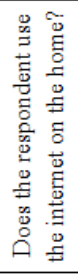 & 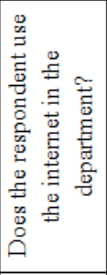 & 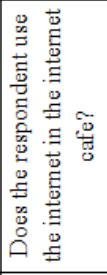 & 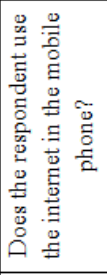 & 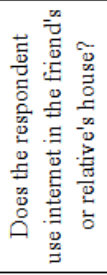 & 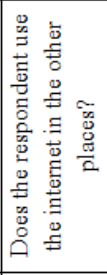 & 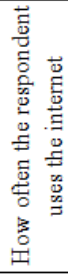 \\
\hline \multirow{2}{*}{$\mathrm{N}$} & Valid & 100 & 100 & 100 & 100 & 100 & 100 & 100 & 100 & 100 & 100 \\
\hline & Missing & 0 & 0 & 0 & 0 & 0 & 0 & 0 & 0 & 0 & 0 \\
\hline Mean & 2.30 & 2.30 & 2.30 & 1.59 & 1.59 & 1.79 & 1.79 & 1.85 & 1.85 & 1.85 & 1.85 \\
\hline Std. Error of Mean & .075 & .075 & .075 & .049 & .049 & .041 & .041 & .036 & .036 & .036 & .036 \\
\hline Mode & 2 & 2 & 2 & 2 & 2 & 2 & 2 & 2 & 2 & 2 & 2 \\
\hline Std. Deviation & .745 & .745 & .745 & .494 & .494 & .409 & .409 & .359 & .359 & .359 & .359 \\
\hline Skewness & .194 & .194 & .194 & -.372 & -.372 & -1.446 & -1.446 & -1.990 & -1.990 & -1.990 & -1.990 \\
\hline
\end{tabular}

a. Multiple modes exist. The smallest value is shown

\begin{tabular}{|c|c|c|c|c|c|c|c|c|c|c|c|c|c|}
\hline 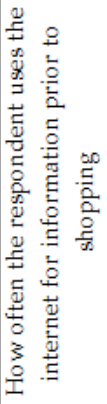 & 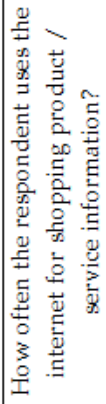 & 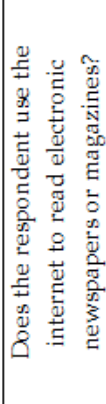 & 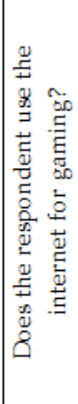 & 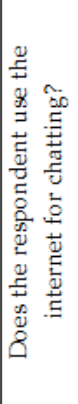 & 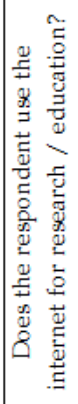 & 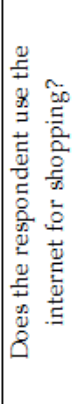 & 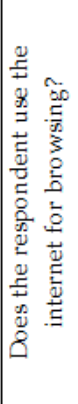 & 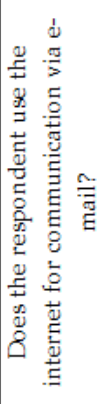 & 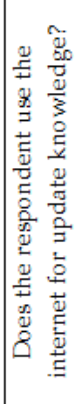 & 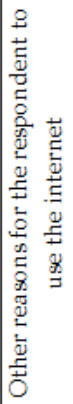 & 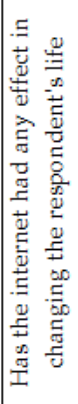 & 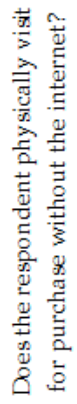 & 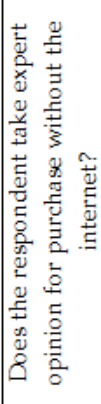 \\
\hline 100 & 100 & 100 & 100 & 100 & 100 & 100 & 100 & 100 & 100 & 100 & 100 & 96 & 100 \\
\hline 0 & 0 & 0 & 0 & 0 & 0 & 0 & 0 & 0 & 0 & 0 & 0 & 4 & 0 \\
\hline 3.56 & 1.22 & 1.40 & 1.15 & 1.28 & 1.59 & 1.31 & 1.00 & 1.62 & 1.49 & 1.00 & 1.00 & 2.45 & 1.12 \\
\hline .139 & .042 & .049 & .036 & .045 & .049 & .046 & .000 & .219 & .050 & .000 & .000 & .064 & .033 \\
\hline 5 & 1 & 1 & 1 & 1 & 2 & 1 & 1 & 1 & 1 & 1 & 1 & 3 & 1 \\
\hline 1.395 & .416 & .492 & .359 & .451 & .494 & .465 & .000 & 2.187 & .502 & .000 & .000 & .642 & .327 \\
\hline-.445 & 1.373 & .414 & 1.990 & .995 & -.372 & .834 & & 4.047 & .041 & & & -.746 & 2.375 \\
\hline
\end{tabular}




\begin{tabular}{|c|c|c|c|c|c|c|c|c|c|c|c|c|c|}
\hline 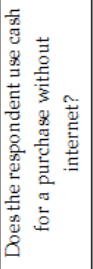 & 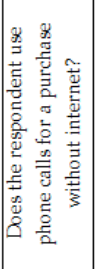 & 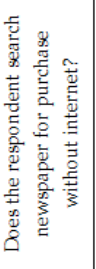 & 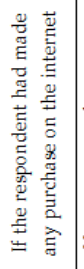 & 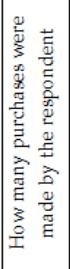 & 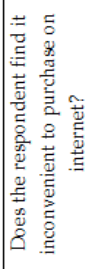 & 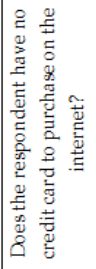 & 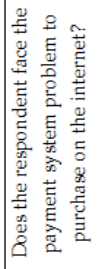 & 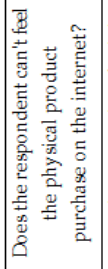 & 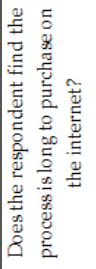 & 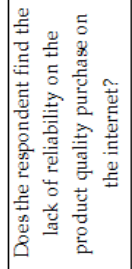 & 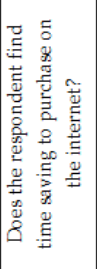 & 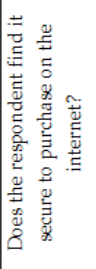 & 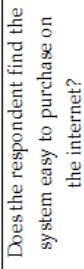 \\
\hline 100 & 100 & 100 & 100 & 100 & 100 & 100 & 100 & 100 & 100 & 100 & 100 & 100 & 100 \\
\hline 0 & 0 & 0 & 0 & 0 & 0 & 0 & 0 & 0 & 0 & 0 & 0 & 0 & 0 \\
\hline 2.11 & 2.05 & 1.54 & 2.41 & 1.41 & 1.51 & 1.99 & 1.57 & 1.59 & 1.55 & 1.52 & 1.43 & 1.11 & 1.59 \\
\hline .080 & .046 & .050 & .124 & .049 & .050 & .088 & .064 & .049 & .074 & .050 & .050 & .031 & .049 \\
\hline 3 & 2 & 2 & 2 & 1 & 2 & 1 & 1 & 2 & 1 & 2 & 1 & 1 & 2 \\
\hline .803 & .458 & .501 & 1.240 & .494 & .502 & .882 & .640 & .494 & .744 & .502 & .498 & .314 & .494 \\
\hline-.203 & .201 & -.163 & 1.119 & .372 & -.041 & .020 & .678 & -.372 & .953 & -.081 & .287 & 2.531 & -.372 \\
\hline
\end{tabular}

\begin{tabular}{|c|c|c|c|c|c|c|c|c|c|c|c|c|c|}
\hline 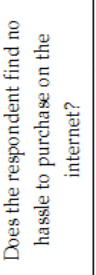 & 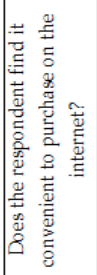 & 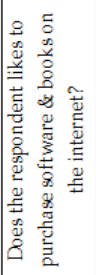 & 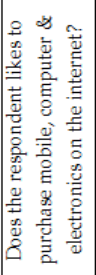 & 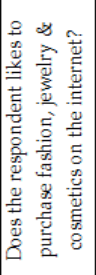 & 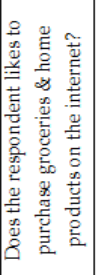 & 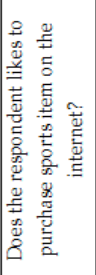 & 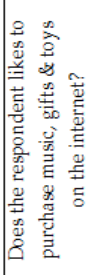 & 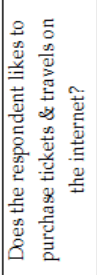 & 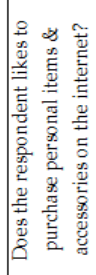 & 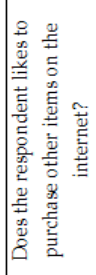 & 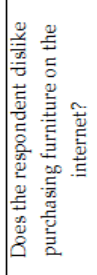 & 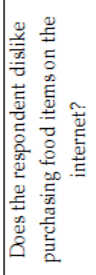 & 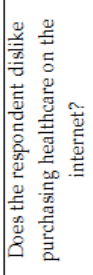 \\
\hline 100 & 100 & 100 & 100 & 100 & 100 & 100 & 100 & 100 & 100 & 100 & 100 & 100 & 100 \\
\hline 0 & 0 & 0 & 0 & 0 & 0 & 0 & 0 & 0 & 0 & 0 & 0 & 0 & 0 \\
\hline 1.30 & 1.10 & 1.54 & 1.52 & 1.65 & 1.40 & 1.20 & 1.87 & 1.75 & 2.05 & 1.18 & 1.33 & 1.55 & 3.31 \\
\hline .046 & .030 & .050 & .050 & .048 & .049 & .040 & .056 & .044 & .067 & .039 & .047 & .070 & 147 \\
\hline 1 & 1 & 2 & 2 & 2 & 1 & 1 & 2 & 2 & 2 & 1 & 1 & 1 & 5 \\
\hline .461 & .302 & .501 & .502 & .479 & 492 & .402 & .562 & .435 & 672 & .386 & .473 & .702 & 1.468 \\
\hline .886 & 2.707 & -.163 & -.081 & -.639 & .414 & 1.523 & -.033 & -1.172 & -.059 & 1.691 & .734 & .893 & -.321 \\
\hline
\end{tabular}

\begin{tabular}{|c|c|c|c|c|c|c|c|c|c|c|c|c|c|}
\hline 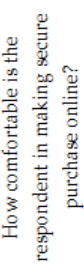 & 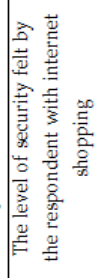 & 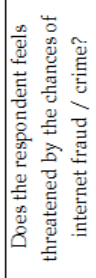 & 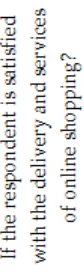 & 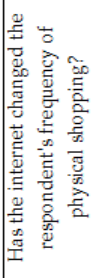 & 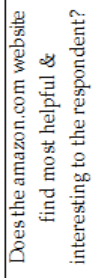 & 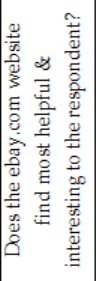 & 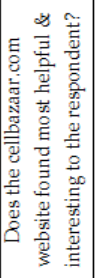 & 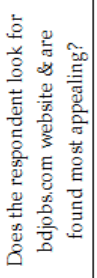 & 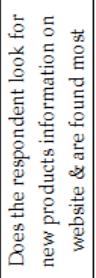 & 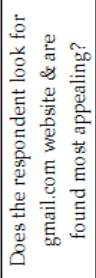 & 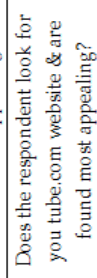 & 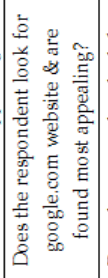 & 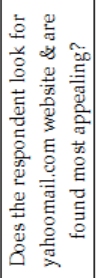 \\
\hline 100 & 100 & 100 & 100 & 100 & 100 & 100 & 100 & 100 & 100 & 100 & 100 & 100 & 100 \\
\hline 0 & 0 & 0 & 0 & 0 & 0 & 0 & 0 & 0 & 0 & 0 & 0 & 0 & 0 \\
\hline 2.09 & 1.42 & 2.79 & 2.33 & 1.11 & 1.10 & 1.10 & 1.00 & 1.39 & 2.10 & 2.00 & 1.40 & 1.92 & 2.02 \\
\hline .124 & .050 & .122 & .088 & .031 & .030 & .030 & .000 & .067 & .030 & .000 & .049 & .027 & .043 \\
\hline 1 & 1 & 2 & 3 & 1 & 1 & 1 & 1 & 1 & 2 & 2 & 1 & 2 & 2 \\
\hline 1.240 & .496 & 1.217 & .877 & .314 & .302 & .302 & .000 & .665 & .302 & .000 & .492 & .273 & .426 \\
\hline .572 & .329 & .585 & -.702 & 2.531 & 2.707 & 2.707 & & 1.466 & 2.707 & & & & \\
\hline
\end{tabular}




\begin{tabular}{|c|c|c|c|c|c|c|c|c|c|c|}
\hline 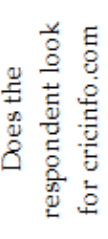 & 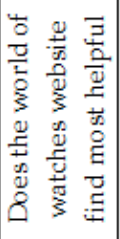 & 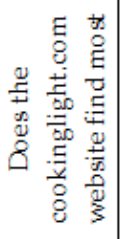 & 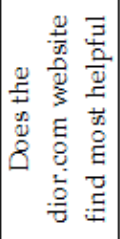 & 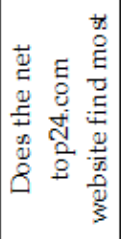 & 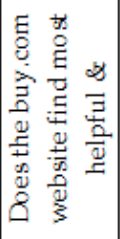 & 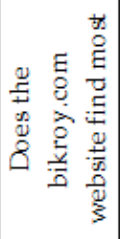 & 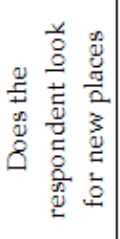 & 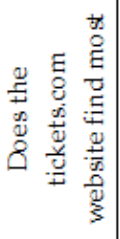 & 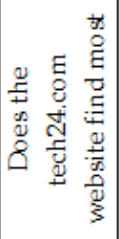 & 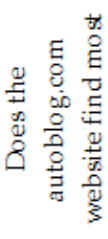 \\
\hline 100 & 100 & 100 & 100 & 100 & 100 & 100 & 100 & 100 & 100 & 100 \\
\hline 0 & 0 & 0 & 0 & 0 & 0 & 0 & 0 & 0 & 0 & 0 \\
\hline 1.90 & 1.92 & 1.52 & 1.11 & 1.00 & 1.00 & 1.00 & 1.64 & 1.27 & 1.48 & \\
\hline .030 & .027 & .050 & .031 & .000 & .000 & .000 & .048 & .045 & .050 & \\
\hline 2 & 2 & 2 & 1 & 1 & 1 & 1 & 2 & 1 & 1 & \\
\hline .302 & .273 & .502 & .314 & .000 & .000 & .000 & .482 & . 446 & .502 & \\
\hline .414 & -3.144 & .123 & -2.707 & -3.144 & -.081 & 2.531 & & & & \\
\hline
\end{tabular}

\section{Descriptive statistics:}

Independent Samples Test

\begin{tabular}{|c|c|c|c|c|c|c|c|c|c|c|}
\hline & & \multicolumn{2}{|c|}{$\begin{array}{c}\text { Levene's Test for } \\
\text { Equality of } \\
\text { Variances }\end{array}$} & \multicolumn{5}{|c|}{ t-test for Equality of Means } & \multicolumn{2}{|c|}{$\begin{array}{l}95 \% \text { Confidence } \\
\text { Interval of the } \\
\text { Difference }\end{array}$} \\
\hline & & $\mathrm{F}$ & Sig. & $\mathrm{t}$ & df & $\begin{array}{l}\text { Sig. }(2- \\
\text { tailed) }\end{array}$ & $\begin{array}{c}\text { Mean } \\
\text { Difference }\end{array}$ & $\begin{array}{l}\text { Std. Error } \\
\text { Difference }\end{array}$ & Lower & Upper \\
\hline \multirow{2}{*}{$\begin{array}{c}\text { How often the respondent } \\
\text { uses internet for information } \\
\text { prior to shopping }\end{array}$} & $\begin{array}{c}\text { Equal variances } \\
\text { assumed }\end{array}$ & 4.147 & .044 & -1.081 & 98 & .283 & -.220 & .204 & -.024 & .184 \\
\hline & $\begin{array}{l}\text { Equal variances } \\
\text { not assumed }\end{array}$ & & & -1.081 & 96.298 & .283 & -.220 & .204 & -.624 & .184 \\
\hline \multirow{2}{*}{$\begin{array}{l}\text { How often the respondent } \\
\text { uses internet for shopping }\end{array}$} & $\begin{array}{c}\text { Equal variances } \\
\text { assumed }\end{array}$ & .337 & .563 & .285 & 98 & .776 & .080 & .280 & -.476 & .636 \\
\hline & $\begin{array}{l}\text { Equal variances } \\
\text { not assumed }\end{array}$ & & & .285 & 97.287 & .776 & .080 & .280 & -.476 & .630 \\
\hline \multirow{2}{*}{$\begin{array}{l}\text { How many purchases were } \\
\text { made by the respondent }\end{array}$} & $\begin{array}{c}\text { Equal variances } \\
\text { assumed }\end{array}$ & 3.001 & .086 & 1.213 & 98 & .228 & .300 & .247 & -.191 & .791 \\
\hline & $\begin{array}{l}\text { Equal variances } \\
\text { not assumed }\end{array}$ & & & 1.213 & 94.988 & .228 & .300 & .247 & -.191 & .791 \\
\hline \multirow{2}{*}{$\begin{array}{c}\text { How comfortable is the } \\
\text { respondent in making secure } \\
\text { purchase online? }\end{array}$} & $\begin{array}{l}\text { Equal variances } \\
\text { assumed }\end{array}$ & .500 & .481 & 1.862 & 98 & .060 & .540 & .290 & -.036 & 1.116 \\
\hline & $\begin{array}{l}\text { Equal variances } \\
\text { not assumed }\end{array}$ & & & 1.862 & 97.988 & .060 & .540 & .290 & -.036 & 1.116 \\
\hline
\end{tabular}

